\title{
PEMBERDAYAAN PEGAWAI DI PEMERINTAH DAERAH PROVINSI SULAWESI TENGAH
}

\author{
PRICYLIA CHINTYA DEWI BUNTUANG \\ ERDIYANSYAH \\ Program Studi S1 Manajemen Fakultas Ekonomi Universitas Tadulako \\ Program Studi Ilmu Administrasi Publik Fakultas Ilmu Sosial dan Ilmu Politik Universitas Tadulako \\ Email: pricyliabuntuang@yahoo.com; edhy_ecc@yahoo.co.id
}

\begin{abstract}
This study aims to analyze employee empowerment in Central Sulawesi Provincial Government. This research is designed descriptively. The location of this research is at work unit of local government area of Central Sulawesi Province by taking employee as population. The number of research samples 308 respondents were determined by stratified random sampling technique. Data collection techniques in this study consist of observation, questionnaires and documentation. The result of the research shows the whole dimension under study, the most powerful dimension in forming employee empowerment in Central Sulawesi Provincial Government is the impact dimension (85,6\%) because in that dimension state that decision and action of employee have influence in organization, while the low dimension is dimension meaning (84.9\%) because the dimension states that employees are less empowered and trusted in the job. The results can also be interpreted that with the empowerment of employees, the result of empowerment makes the decisions and actions of employees to be influential in the organization, but overall employees tend to be less empowered and trusted in carrying out their work.
\end{abstract}

Keywords: empowerment, employe, organization.

\section{ABSTRAK}

Penelitian ini bertujuan untuk menganalisis pemberdayaan pegawai di Pemerintah Daerah Provinsi Sulawesi Tengah. Penelitian ini didesain secara deskriptif. Lokasi penelitian ini di satuan kerja perangkat daerah Pemerintah Daerah Provinsi Sulawesi Tengah dengan mengambil pegawai sebagai populasi. Jumlah sampel penelitian 308 responden yang ditentukan dengan teknik stratified random sampling. Teknik pengumpulan data dalam penelitian ini terdiri dari observasi, kuesioner dan dokumentasi. Hasil penelitian menunjukkan keseluruhan dimensi yang diteliti, dimensi yang paling kuat dalam membentuk pemberdayaan pegawai di Pemerintah Daerah Provinsi Sulawesi Tengah adalah dimensi impact $(85,6 \%)$ karena pada dimensi tersebut menyatakan bahwa keputusan dan tindakan pegawai berpengaruh dalam organisasi, sedangkan dimensi yang rendah adalah dimensi meaning $(84,9 \%)$ karena dimensi tersebut menyatakan bahwa pegawai kurang diberdayakan dan dipercaya dalam pekerjaan. Hasil tersebut juga dapat dimaknai bahwa dengan adanya pemberdayaan pegawai maka hasil dari pemberdayaan tersebut membuat keputusan dan tindakan pegawai menjadi berpengaruh dalam organisasi, namun secara keseluruhan pegawai cenderung kurang diberdayakan dan dipercaya dalam menjalankan pekerjaannya.

Kata kunci: pemberdayaan, pegawai, organisasi.

\section{PENDAhuluan}

Pemberdayaan sumber daya manusia merupakan salah satu upaya yang wajib dilakukan bagi terciptanya sumber daya manusia yang berkualitas, memiliki kemampuan memanfaatkan, mengembangkan dan menguasai ilmu pengetahuan dan teknologi serta kemampuan menajemen (Leovani, 2016:248). Menurut Sedarmayanti (2010:123) pemberdayaan sumber daya manusia merupakan salah satu upaya yang wajib dilakukan bagi terciptanya sumber daya manusia yang berkualitas, memiliki kemampuan memanfaatkan, mengembangkan dan menguasai ilmu pengetahuan dan teknologi serta kemampuan menajemen. Pegawai yang mendapatkan pemberdayaan secara benar akan memiliki kompetensi yang lebih baik. 
Pemberdayaan pegawai dituntut untuk bisa memberdayakan pegawai agar memiliki tanggung jawab dan ketrampilan kerja yang lebih besar.

Pemberdayaan pegawai berarti memampukan dan memberi kesempatan kepada pegawai untuk melakukan fungsi-fungsi manajemen dalam skala yang menjadi tanggungjawabnya, baik secara individu maupun kelompok. Jika hal tersebut belum tercapai maka proses pemberdayaan belum dilakukan. Fenomena di lapangan menunjukkan pegawai belum diberdayakan secara maksimal, karena pegawai yang ada hanya diberi tugas pokok dan fungsi masing-masing tanpa harus mengikuti pelatihan-pelatihan ataupun seminar/workshop yang dilaksanakan internal dinas maupun dari eksternal. Keikutsertaan pegawai dalam seminar/workshop yang kaitannya dengan tugas pokok dan fungsi masing-masing pegawai sebagian besar hanya terwakili. Hal ini berdampak pada pengetahuan pegawai yang ada, karena dalam hal informasi yang didapatkan melalui keterwakilan tersebut pastinya tidak akurat sehingga hasil seminar/workshop menjadi kurang bermanfaat, sementara dalam seminar/workshop yang dilaksanakan banyak ilmu dan pengetahuan serta informasi yang bermanfaat dalam menunjang perubahan yang dilaksanakan.

Kemajuan teknologi saat ini merupakan salah satu pendukung bagi pegawai dalam mengembangkan pengetahuannya. Pegawai dapat mencari informasi dengan menggunakan teknologi canggih melalui media online, dengan demikian informasi yang didapatkan sangat cepat dan terbaru yang dapat menunjang pegawai dalam menghadapi perubahan, namun fenomena yang terlihat mengindikasikan bahwa pegawai SKPD di lingkungan Pemerintah Daerah Provinsi Sulawesi Tengah masih banyak yang kurang memahami dan kurang pengetahuan terkait dengan penggunan IT (informasi teknologi).

Berdasarkan uraian yang dikemukakan, maka tujuan penelitian ini adalah untuk menganalisis pemberdayaan pegawai di Pemerintah Daerah Provinsi Sulawesi Tengah.

\section{KAJIAN LITERATURE}

\section{Pemberdayaan}

Empowerment/pemberdayaan asalnya dari kata "power" yang artinya "contol, authority, dominion". Awalan "emp" artinya "on put to" atau "to cover with". jelasnya "more power". Jadi "empowering" artinya "is passing on authority and responsibility", yaitu lebih berdaya dari sebelumnya dalam arti wewenang dan tanggung jawabnya termasuk kemampuan individual yang dimilikinya (Sedarmayanti, 2010:285).

Robbins \& Coulter (2009:401) mendefinisikan pemberdayaan (empowerment) sebagai "the act of increasing the decision making discretion of workers". Pandangan tersebut dapat dimaknai bahwa pemberdayaan sebagai suatu tindakan meningkatkan kebijakan pengambilan keputusan para pekerja. Selain itu dapat juga dimaknai sebagai pemberian tanggung jawab sepenuhnya kepada karyawan atas apa yang mereka lakukan, dan dengan demikian manajer/pimpinan dipaksa untuk belajar melepas kendali, sementara karyawan dipaksa untuk belajar bertanggung jawab atas kerja mereka dan membuat keputusan-keputusan yang tepat.

Selanjutnya empowerment (pemberdayaan) menurut Bateman \& Snell (2008:79) adalah proses berbagi kekuasaan dengan para pekerja, sehingga meningkatkan kepercayaan diri dalam melaksanakan pekerjaan dan meyakinkan pekerja bahwa mereka adalah kontributor yang berpengaruh bagi organisasi. Pandangan tersebut menggambarkan bahwa pemberdayaan merupakan proses pemberian kekuasaan kepada karyawan sehingga dengan demikian akan 
menimbulkan kepercayaan diri karyawan dalam bekerja dan menganggap dan meyakini bahwa mereka (karyawan) memiliki pengaruh terhadap organisasi.

Pandangan lain dikemukakan Schemerhorn et al. (2005:276) bahwa "empowerment is the process by which menegers help others to acquire and use the power needed to make decisions affecting themselves and their work". Pandangan tersebut dapat dimaknai sebagai proses di mana manajer membantu orang lain (karyawan) mendapatkan dan menggunakan daya yang dibutuhkan untuk membuat keputusan yang berdampak pada diri sendiri dan pekerjaan mereka. Pandangan tersebut dipertegas Conger \& Kanungo dalam Anita et al. (2007:569) yang menyatakan bahwa "empowerment is the act of strengthening an individual's beliefs in his/her sense of effectiveness - a process of changing the internal beliefs of people". Pandangan tersebut senada dengan pandangan sebelumnya bahwa pemberdayaan merupakan tindakan memperkuat keyakinan individu dalam merasakan keefektifan dan pemberdayaan merupakan sebuah proses mengubah keyakinan internal orang. Pandangan tersebut lebih luas diartikan sebagai pemberian keprecayaan kepada seseorang atau individu dapat mengubah perilaku orang atau individu tersebut ke arah yang lebih baik. Lebih lanjut Langbein (2000); Dainty et al. (2002); Arneson \& Ekberg (2006) dalam Baird \& Wang (2010:577) menjelaskan bahwa "employee empowerment refers to the delegation of power and responsibility from higher levels in the organizational hierarchy to lower level employees, especially the power to make decisions". Pandangan tersebut menjelaskan bahwa pemberdayaan karyawan mengacu pada pendelegasian kekuasaan dan tanggung jawab dari tingkat yang lebih tinggi dalam hirarki organisasi kepada karyawan tingkat yang lebih rendah, terutama kekuatan untuk membuat keputusan.

Karim \& Rehman (2012:96) menyatakan bahwa "employee empowerment prevailed by sharing information, enhancing intellectual capacity and autonomy while making decisions". Pandangan tersebut memberikan makna bahwa pemberdayaan karyawan dilakukan dengan berbagi informasi, meningkatkan kemampuan intelektual, dan kemandirian saat membuat keputusan. Artinya bahwa karyawan yang diberdayakan dapat meningkatkan kemampaun karena adanya kemandirian dalam mengambil keputusan. Senada dengan pandangan tersebut, Hales \& Klidas dalam Pellit et al. (2011:785) "define empowerment as sharing knowledge, information and power with subordinate". Pandangan tersebut menjelaskan bahwa pemberdayaan sebagai upaya berbagi pengetahuan, informasi dan kekuatan dengan bawahan. Artinya bahwa melalui pemberdayaan, individu dalam suatu organisasi saling membagi pengetahuan dan informasi untuk saling melengkapi.

Pandangan Conger et al. dalam Abraiz \& Tabassum (2012:393) menjelaskan bahwa "empowerment includes individual motivation increased at job through the allocation of autonomy to the low level in an organization proficient decision can be made". Pandangan tersebut dimaknai bahwa pemberdayaan dapat meningkatkan motivasi individu terhadap pekerjaan melalui alokasi dari kemandirian ke tingkat rendah dalam keputusan mahir organisasi dapat dilakukan. Selanjutnya pandangan yang dikemukakan oleh Liden et al. Abraiz \& Tabassum (2012:393) menyatakan bahwa "explained the empowerment as intrinsic motivation, job design, collaborative decision making, social learning theory, and self management". Pandangan tersebut juga menjelaskan bahwa pemberdayaan sebagai motivasi intrinsik, desain pekerjaan, pengambilan keputusan kolaboratif, teori belajar sosial, dan manajemen diri. Namun dapat dilihat maksud dari kedua pandangan tersebut yang 
menitikberatkan bahwa pemberdayaan merupakan suatu motivasi yang ada dalam diri individu ata seseorang.

\section{Dimensi Pemberdayaan}

Penelitian Thomas \& Velthouse (1990) menjelaskan bahwa "defining empowerment as "internal motivation that can be explained by four perceptive dimensions, which are sense, competence, choice and impact". Penjelasan atas hasil penelitian tersebut dapat dimaknai bahwa pemberdayaan sebagai motivasi internal yang dapat dijelaskan oleh empat dimensi perseptif, yaitu akal, kompetensi, pilihan, dan dampaknya.

Pandangan lain juga dikemukakan oleh McShane \& Von Glinow (2010:182) mendefinisikan pemberdayaan yaitu "empowerment is a psychological concept in which people experience more self-determination, meaning, competence, and impact regarding their role in the organization". Pandangan tersebut menggambarkan bahwa pemberdayaan sebagai konsep psikologis di mana orang mengalami lebih banyak upaya untuk menentukan nasib sendiri, makna, kompetensi, dan dampaknya mengenai peran mereka dalam organisasi. Konsep psikologis tersebut menurut McShane \& Von Glinow (2010:182) diwakili oleh empat dimensi.

\section{1) Self determination}

Empowered employees feel that they have freedom, independence, and discretion over their work activities.

\section{2) Meaning}

Employees who feel empowered care about their work and belive that what they do is important

\section{3) Competence}

Empowered people are confident about their ability to perform the work well and have a capacity to grow with new challenges

\section{4) Impact}

Empowered employees view themselves as active participants in the organization, that is, their decision and actions have an influence on the company's succes.

Konsep psikologis yang mewakili pemberdayaan menjelaskan bahwa dimensi self determination (menentukan nasib sendiri) dapat dimaknai sebagai proses di mana karyawan diberdayakan dengan menunjukkan bahwa karyawan memiliki kebebasan, kemerdekaan, dan kebijaksanaan terhadap aktivitas kerja mereka. Dimensi meaning (makna) dimaknai sebagai proses di mana karyawan diberdayakan dalam pekerjaan dan percaya bahwa apa yang dilakukan karyawan adalah penting. Dimensi competence (kompetensi) menjelaskan bahwa karyawan yang diberdayakan memiliki keyakinan tentang kemampuannya untuk melakukan pekerjaan dengan baik dan memiliki kapasitas untuk tumbuh dengan tantangan baru. Sedangkan dimensi impact (dampak) menjelaskan bahwa karyawan yang diberdayakan melihat diri mereka sebagai peserta aktif dalam organisasi, yaitu keputusan dan tindakan mereka memiliki pengaruh terhadap kesuksesan perusahaan.

Berdasarkan dari uraian dan penjelasan dimensi pemberdayaan, maka teori pemberdayaan yang digunakan dan dijadikan dasar dalam penelitian ini adalah teori pemberdayaan dari McShane \& Von Glinow (2010:182) yang mengemukakan empat dimensi pemberdayaan yang terdiri dari dimensi self determination, meaning, competence, and impact. 


\section{METODE PENELITIAN}

Penelitian ini didesain secara deskriptif. Lokasi penelitian ini di satuan kerja perangkat daerah Pemerintah Daerah Provinsi Sulawesi Tengah dengan mengambil pegawai sebagai populasi. Populasi dalam penelitian ini adalah seluruh pegawai dengan jumlah secara kesluruhan adalah 3078 pegawai untuk seluruh SKPD. Penelitian ini memfokuskan pada 11 SKPD dengan jumlah pegawai sebanyak 1335 orang sebagaimana Tabel 1 berikut.

Tabel 1 Populasi Penelitian

\begin{tabular}{|c|l|c|c|c|c|c|}
\hline \multirow{2}{*}{ No. Satuan Kerja Perangkat Daerah (SKPD) } & \multicolumn{3}{|c|}{ Pangkat/Gol } & \multirow{2}{*}{ Jumlah } \\
\cline { 3 - 5 } & \multicolumn{1}{|c|}{ I } & II & III & IV & \\
\hline 1 & Dinas Pendidikan dan Kebudayaan Daerah & 4 & 40 & 218 & 53 & 315 \\
\hline 2 & Dinas Kesehatan Daerah & 2 & 16 & 135 & 14 & 167 \\
\hline 3 & Dinas Kehutanan Daerah & 1 & 14 & 71 & 12 & 98 \\
\hline 4 & Dinas Pertanian Daerah & 2 & 18 & 79 & 12 & 111 \\
\hline 5 & Dinas Pariwisata dan Ekonomi Kreatif & 0 & 15 & 66 & 11 & 92 \\
\hline 6 & Dinas Koperasi, UMKM, Perindustrian, dan Perdagangan Daerah & 1 & 11 & 132 & 16 & 160 \\
\hline 7 & Dinas Perhubungan Daerah & 2 & 12 & 67 & 13 & 94 \\
\hline 8 & Dinas Komunikasi dan Informatika Daerah & 2 & 17 & 79 & 14 & 112 \\
\hline 9 & Dinas Bina Marga Daerah & 1 & 14 & 37 & 10 & 62 \\
\hline 10 & Dinas Sumber Daya Air Daerah & 0 & 16 & 35 & 9 & 60 \\
\hline 11 & Dinas Cipta Karya, Perumahan dan Tata Ruang Daerah & 2 & 15 & 36 & 11 & 64 \\
\hline & Total Jumlah & $\mathbf{1 7}$ & $\mathbf{1 8 8}$ & $\mathbf{9 5 5}$ & $\mathbf{1 7 5}$ & $\mathbf{1 3 3 5}$ \\
\hline
\end{tabular}

Pengambilan sampel menggunakan rumus dari Taro Yamane dalam Riduwan (2010:65) sebagai berikut:

$$
\begin{aligned}
& \text { Keterangan: } \\
& \mathrm{n}=\text { Jumlah Sampel } \\
& \mathrm{N}=\text { Jumlah Populasi } \\
& \mathrm{d}^{2}=\text { Presisi (ditetapkan } 5 \% \text { ) }
\end{aligned}
$$

Maka besarnya sampel dapat dihitung sebagai berikut.

Prosedur pengambilan sampel pada penelitian ini menggunakan teknik stratified random sampling. Nazir (2011:291) menjelaskan bahwa stratified random sampling adalah sampel yang ditarik dengan memisahkan elemen-elemen populasi dalam kelompok-kelompok yang tidak overlapping yang disebut strata, dan kemudian memilih sebuah sampel secara random dari setiap stratum. Sampel pada penelitian ini dapat dilihat dari rician Tabel 2 berikut. 
Tabel 2 Sampel Penelitian

\begin{tabular}{|c|c|c|c|c|c|c|}
\hline \multirow{2}{*}{ No. } & \multirow{2}{*}{ Satuan Kerja Perangkat Daerah (SKPD) } & \multicolumn{4}{|c|}{ Pangkat/Gol } & \multirow[b]{2}{*}{ Jumlah } \\
\hline & & I & II & III & IV & \\
\hline 1 & Dinas Pendidikan dan Kebudayaan Daerah & 1 & 9 & 50 & 12 & 73 \\
\hline 2 & Dinas Kesehatan Daerah & 1 & 4 & 31 & 3 & 39 \\
\hline 3 & Dinas Kehutanan Daerah & 1 & 3 & 16 & 3 & 23 \\
\hline 4 & Dinas Pertanian Daerah & 0 & 4 & 18 & 3 & 26 \\
\hline 5 & Dinas Pariwisata dan Ekonomi Kreatif & 0 & 3 & 15 & 3 & 21 \\
\hline 6 & Dinas Koperasi, UMKM, Perindustrian, dan Perdagangan & 0 & 3 & 30 & 4 & 37 \\
\hline 7 & Dinas Perhubungan Daerah & 1 & 3 & 15 & 3 & 22 \\
\hline 8 & Dinas Komunikasi dan Informatika Daerah & 1 & 4 & 18 & 3 & 26 \\
\hline 9 & Dinas Bina Marga Daerah & 0 & 3 & 9 & 2 & 14 \\
\hline 10 & Dinas Sumber Daya Air Daerah & 0 & 4 & 8 & 2 & 14 \\
\hline 11 & Dinas Cipta Karya, Perumahan dan Tata Ruang Daerah & 1 & 3 & 8 & 3 & 15 \\
\hline & Total Jumlah & 6 & 43 & 218 & 41 & 308 \\
\hline
\end{tabular}

\section{HASIL DAN PEMBAHASAN}

\section{Pemberdayaan Pegawai di Pemerintah Daerah Provinsi Sulawesi Tengah}

Pengembangan pegawai melalui pemberdayaan yang dilakukan SKPD Pemerintah Daerah Provinsi Sulawesi Tengah dapat memberikan kesan bahwa pegawai diperhatikan oleh SKPD. Pemberdayaan pegawai dalam penelitian ini dilakukan dengan beberapa dimensi, di antaranya self determination, meaning, competence dan impact.

\section{1) Dimensi Self Determination}

Pengukuran dimensi self determination pada penelitian ini dilihat dari 2 (dua) pertanyaan/pernyataan dengan indikator penelitian yaitu kebebasan dan kemerdekaan serta kebijaksanaan terhadap aktivitas kerja. Hasil tanggapan responden pada dimensi self determination dapat dilihat dari hasil deskriptif pada Tabel 3 berikut.

Tabel 3 Deskriptif Dimensi Self Determination

\begin{tabular}{|c|c|c|c|c|c|c|c|c|c|}
\hline \multirow{3}{*}{ Skala } & \multicolumn{6}{|c|}{ Item Pertanyaan/Pernyataan } & \multirow{2}{*}{\multicolumn{3}{|c|}{ Dimensi Kumulatif }} \\
\hline & \multicolumn{3}{|c|}{1} & \multicolumn{3}{|c|}{1} & & & \\
\hline & $\mathbf{F}$ & $\%$ & Skor & $\mathbf{F}$ & $\%$ & Skor & $\mathbf{f}$ & $\%$ & Skor \\
\hline 1 & 0 & 0,0 & 0 & 0 & 0,0 & 0 & 0 & 0,0 & 0 \\
\hline 2 & 0 & 0,0 & 0 & 3 & 1,0 & 6 & 3 & 0,5 & 6 \\
\hline 3 & 18 & 5,8 & 54 & 26 & 8,4 & 78 & 44 & 7,1 & 132 \\
\hline 4 & 173 & 56,2 & 692 & 189 & 61,4 & 756 & 362 & 58,8 & 1448 \\
\hline 5 & 117 & 38,0 & 585 & 90 & 29,2 & 450 & 207 & 33,6 & 1035 \\
\hline $\begin{array}{c}\text { Total } \\
\text { Capaian }\end{array}$ & 308 & 100 & 1331 & 308 & 100 & 1290 & 616 & 100 & 2621 \\
\hline \multicolumn{3}{|c|}{ Skor Max } & 1540 & & & 1540 & & & 3080 \\
\hline \multicolumn{3}{|c|}{ Total Skor (\%) } & 86,4 & & & 83,8 & & & 85,1 \\
\hline
\end{tabular}

Sumber: Hasil Olahan Data Penelitian.

Tabel 3 mendeskripsikan dimensi self determination secara kumulatif dapat diinterpretasikan pada kriteria sangat maksimal $(85,1 \%)$. Ini artinya bahwa pegawai diberdayakan secara maksimal, terutama pada item pertanyaan/pernyataan nomor 1 tentang pemberdayaan dalam hal pemberian kebebasan dan kemerdekaan bekerja 86,4\%), sedangkan item pertanyaan/pernyataan nomor 2 menunjukkan persentase total skor rendah $(83,8 \%)$ yang memberikan makna bahwa pegawai kurang mendapat kebijaksanaan dalam bekerja. 
Hasil tersebut secara umum memberikan makna bahwa dimensi self determination pada penelitian ini menunjukkan proses pemberdayaan pegawai sangat ditekankan pada pemberian kebebasan dan kemerdekaan pegawai dalam bekerja yang dapat diartikan bahwa atasan atau organisasi tidak mengintervensi pegawainya dalam melaksanakan pekerjaanya.

\section{2) Dimensi Meaning}

Dimensi meaning dalam penelitian ini dilihat dari 2 (dua) item pertanyaan/pernyataan yang terdiri dari indikator memanfatkan pegawai dan pemberian pekerjaan. Tabel 4 menggambarkan bahwa secara kumulatif dimensi meaning berada pada kriteria interpretasi sangat maksimal $(84,9 \%)$, terutama pada item pertanyaan/pernyataan nomor 3 tentang indikator pentingnya keberadaan pegawai dengan persentase total skor tertinggi $(85,5 \%)$. Hasil tersebut memberikan makna bahwa apa yang dilakukan pegawai dalam organisasi sangat penting sehingga organisasi memanfatkan semaksimal mungkin potensi pegawai untuk kemajuan organisasi, namun disisi lain pegawai kurang diberdayakan dan dipercaya dalam pekerjaannya.

Tabel 4. Deskriptif Dimensi Meaning

\begin{tabular}{|c|c|c|c|c|c|c|c|c|c|}
\hline \multirow{3}{*}{ Skala } & \multicolumn{6}{|c|}{ Item Pertanyaan/Pernyataan } & \multirow{2}{*}{\multicolumn{3}{|c|}{ Dimensi Kumulatif }} \\
\hline & \multicolumn{3}{|c|}{3} & \multicolumn{3}{|c|}{4} & & & \\
\hline & $\mathbf{F}$ & $\%$ & Skor & $\mathbf{F}$ & $\%$ & Skor & f & $\%$ & Skor \\
\hline 1 & 0 & 0,0 & 0 & 0 & 0,0 & 0 & 0 & 0,0 & 0 \\
\hline 2 & 0 & 0,0 & 0 & 0 & 0,0 & 0 & 0 & 0,0 & 0 \\
\hline 3 & 27 & 8,8 & 81 & 24 & 7,8 & 72 & 51 & 8,3 & 153 \\
\hline 4 & 170 & 55,2 & 680 & 192 & 62,3 & 768 & 362 & 58,8 & 1448 \\
\hline 5 & 111 & 36,0 & 555 & 92 & 29,9 & 460 & 203 & 33,0 & 1015 \\
\hline Total Capaian & 308 & 100 & 1316 & 308 & 100 & 1300 & 616 & 100 & 2616 \\
\hline \multicolumn{3}{|l|}{ Skor Max } & 1540 & & & 1540 & & & 3080 \\
\hline \multicolumn{3}{|l|}{ Total Skor $(\%)$} & 85,5 & & & 84,4 & & & 84,9 \\
\hline
\end{tabular}

Sumber: Hasil Olahan Data Penelitian.

\section{3) Dimensi Competence}

Pengukuran dimensi competence dalam penelitian ini dilihat dari 2 (dua) item pertanyaan/pernyataan dengan indikator yang terdiri dari memiliki keyakinan atas kemampuan dan memiliki kapasitas. Indikator-indikator tersebut merupakan pembentuk dari kompetensi pegawai, di mana hasil deskriptif dari dimensi tersebut dapat dilihat berikut.

Tabel 5 Deskriptif Dimensi Competence

\begin{tabular}{|c|c|c|c|c|c|c|c|c|c|}
\hline \multirow{3}{*}{ Skala } & \multicolumn{6}{|c|}{ Item Pertanyaan/Pernyataan } & \multirow{2}{*}{\multicolumn{3}{|c|}{ Dimensi Kumulatif }} \\
\hline & \multicolumn{3}{|c|}{5} & \multicolumn{3}{|c|}{6} & & & \\
\hline & $\mathbf{F}$ & $\%$ & Skor & $\mathbf{F}$ & $\%$ & Skor & f & $\%$ & Skor \\
\hline 1 & 0 & 0,0 & 0 & 0 & 0,0 & 0 & 0 & 0,0 & 0 \\
\hline 2 & 5 & 1,6 & 10 & 5 & 1,6 & 10 & 10 & 1,6 & 20 \\
\hline 3 & 15 & 4,9 & 45 & 23 & 7,5 & 69 & 38 & 6,2 & 114 \\
\hline 4 & 179 & 58,1 & 716 & 175 & 56,8 & 700 & 354 & 57,5 & 1416 \\
\hline 5 & 109 & 35,4 & 545 & 105 & 34,1 & 525 & 214 & 34,7 & 1070 \\
\hline Total Capaian & 308 & 100 & 1316 & 308 & 100 & 1304 & 616 & 100 & 2620 \\
\hline \multicolumn{3}{|l|}{ Skor Max } & 1540 & & & 1540 & & & 3080 \\
\hline \multicolumn{3}{|l|}{ Total Skor (\%) } & 85,5 & & & 84,7 & & & 85,1 \\
\hline
\end{tabular}

Sumber: Hasil Olahan Data Penelitian. 
Hasl analisis deskriptif dalam Tabel 5 menggambarkan bahwa secara kumulatif, dimensi competence dapat diinterpretasikan pada kriteria interpretasi sangat maksimal $(85,1 \%)$. Hasil tersebut mengartikan bahwa pemberdayaan pegawai dilakukan secara maksimal, terutama dengan memberikan keyakinan atas kemampuan pegawai dengan tujuan untuk menciptakan kompetensi pegawai. Hal tersebut ditunjukkan melalui hasil deskriptif pada item pertanyaan/pernyataan nomor 5 dengan indikator keyakinan atas kemampuan yang dengan persentase total skor tertinggi $(85,5 \%)$. Keyakinan atas kemampuan yang dimiliki pegawai didapatkan setelah pegawai diberdayakan.

\section{4) Dimensi Impact}

Hasil analisis deskriptif berikut menjelaskan bahwa dimensi impact terdiri dari 2 (dua) item pertanyaan/pernyataan dengan indikator penelitian yang terdiri dari aktif dalam organisasi serta keputusan dan tindakan. Hasil analisis deskriptif dari indikator tersebut dapat dilihat berikut.

Tabel 6 Deskriptif Dimensi Impact

\begin{tabular}{|c|c|c|c|c|c|c|c|c|c|}
\hline \multirow{3}{*}{ Skala } & \multicolumn{6}{|c|}{ Item Pertanyaan/Pernyataan } & \multirow{2}{*}{\multicolumn{3}{|c|}{ Dimensi Kumulatif }} \\
\hline & \multicolumn{3}{|c|}{7} & \multicolumn{3}{|c|}{8} & & & \\
\hline & $\mathbf{F}$ & $\%$ & Skor & $\mathbf{F}$ & $\%$ & Skor & f & $\%$ & Skor \\
\hline 1 & 0 & 0,0 & 0 & 0 & 0,0 & 0 & 0 & 0,0 & 0 \\
\hline 2 & 0 & 0,0 & 0 & 3 & 1,0 & 6 & 3 & 0,5 & 6 \\
\hline 3 & 22 & 7,1 & 66 & 28 & 9,1 & 84 & 50 & 8,1 & 150 \\
\hline 4 & 158 & 51,3 & 632 & 178 & 57,8 & 712 & 336 & 54,5 & 1344 \\
\hline 5 & 128 & 41,6 & 640 & 99 & 32,1 & 495 & 227 & 36,9 & 1135 \\
\hline Total Capaian & 308 & 100 & 1338 & 308 & 100 & 1297 & 616 & 100 & 2635 \\
\hline \multicolumn{3}{|l|}{ Skor Max } & 1540 & & & 1540 & & & 3080 \\
\hline \multicolumn{3}{|l|}{ Total Skor (\%) } & 86,9 & & & 84,2 & & & 85,6 \\
\hline
\end{tabular}

Sumber: Hasil Olahan Data Penelitian.

Tabel 6 yang dikemukakan mendeskripsikan bahwa secara kumulatif dimensi impact dapat diinterpretasikan pada kriteria sangat maksimal $(85,6 \%)$. Dikatakan sangat maksimal karena item pertanyaan/pernyataan nomor 7 dengan indikator keputusan dan tindakan pegawai berpengaruh memiliki persentse total skor tertinggi $(86,9 \%)$, sementara pemberdayaan pegawai melalui keaktifan dalam oranisasi cenderung rendah meskipun jika diinterpretasikan berada pada kriteria sangat maksimal. Namun jika dimaknai bahwa dalam hal pemberdayaan pegawai, 11 SKPD di jajaran Pemerintah Daerah Provinsi Sulawesi Tengah memberikan pemberdayaan kepada pegawai, namun dalam hal pemberian keaktifan dalam organisasi, pegawai cenderung tidak diberdayakan sebagaimana ditunjukkan dalam hasil analisis deskriptif.

\section{KESIMPULAN DAN SARAN}

\section{Kesimpulan}

Berdasarkan hasil analisis pembahasan yang dilakukan, disimpulkan bahwa keseluruhan dimensi yang diteliti, dimensi yang paling kuat dalam membentuk pemberdayaan pegawai di Pemerintah Daerah Provinsi Sulawesi Tengah adalah dimensi impact $(85,6 \%)$ karena pada dimensi tersebut menyatakan bahwa keputusan dan tindakan pegawai berpengaruh dalam organisasi, sedangkan dimensi yang rendah adalah dimensi meaning $(84,9 \%)$ karena dimensi 
tersebut menyatakan bahwa pegawai kurang diberdayakan dan dipercaya dalam pekerjaan. Hasil tersebut juga dapat dimaknai bahwa dengan adanya pemberdayaan pegawai maka hasil dari pemberdayaan tersebut membuat keputusan dan tindakan pegawai menjadi berpengaruh dalam organisasi, namun secara keseluruhan pegawai cenderung kurang diberdayakan dan dipercaya dalam menjalankan pekerjaannya.

\section{Saran}

Berdasarkan hasil kesimpulan yang dikemukakan, maka disarankan kepada Pemerintah Daerah Provinsi Sulawesi Tengah yang dalam hal ini Satuan Kerja Perangkat Daerah (SKPD) agar memperhatikan masalah pemberdayaan, terutama masalah pemberdayaan pegawai yang ditemukan dalam penelitian ini masih kurang maksimal, sehingga diharapkan kedepannya lebih memberdayakan, bahkan mempercayai pegawai dalam menjalankan tugas pokok dan fungsinya.

\section{REFERENSI}

Abraiz, Aneela., and Tabassum, Tahira Malik. (2012). Empowerment Effects and Employees Job Satisfaction. Academic Research International Journal. Vol. 3, No. 3, 392-400.

Anita M.M , W.M Chiu., and Richard Fellows. (2007). Enhancing Commitment Through Work Empowerment. Enhancing, Construction and Architectural Management. Emerald Group Publishing Limited. Vol. 14, No. 6, 568-580.

Bateman, S. Thomas., and Snell, Scott A. (2008). Manajemen (Kepemimpinan dan Kolaborasi dalam Dunia yang Kompotitif). Buku 1. Terjemahan Chriswan Sungkono dan Ali Akbar Yulianto. Jakarta: Salemba Empat.

Baird, K. \& Wang, H. (2010). Employee Empowerment: extent of adoption and influential factors. Personnel Review, 39(5). pp. 574-599

Karim, F., and Rehman, O. (2012). Impact of Job Satisfaction, Perceived Organizational Justice and Employe Empowerment on Organizational Commitment in Semi Government Organizational of Pakistan. Journal of Business Studies Quarterly. Vol. 3, No. 4, 92-104.

Leovani, E. (2016). Implementasi Model Pemberdayaan Karyawan (Employee Empowerment) di PT FIFGROUP Tbk Cabang Palembang. Jurnal Manajemen, Vol. 20, No. 2, 245-261.

McShane, Steven L., and Von Glinow, Mary Ann. (2010). Organizational Behavior, Emerging Knowledge and Practice for The Real World. Fifth Edition. America: McGraw-Hill/Irwin.

Nazir, Moh. 2011. Metode Penelitian. Bogor: Ghalia Indonesia.

Pellit, Elbeyi., Ozturk, Yuksel., and Arslanturk, Yalcin. (2011). The Effects of Employee Empowerment on Employee Job Satisfaction a Study on Hotels in Turkey. International Journal of Contemporary Hospitality Management. Emerald Group Publishing Limited, Vol. 23, No. 6, 784-802.

Riduwan. 2010. Metode dan Teknik Menyusun Tesis. Bandung: Alfabeta.

Robbins, Staphen P \& Coulter, Mary. (2009). Management. Tenth Edition. Pearson International Editional. United States of America: Pearson Prentice Hall.

Schemerhorn, John R. Jr., James G Hunt, \& Richard N Osborn. (2005). Organizational Behavior. Ninth Edition. America: Wileu \& Sons, Inc.

Sedarmayanti. (2010). Manajemen Sumber Daya Manusia Reformasi Birokrasi dan Manajemen Pegawai Negeri Sipil. Bandung: PT Refka Aditama. 
Thomas, K. W., and B. A. Velthouse. 1990. Cognitive elements of empowerment: an "interpretive" model of intrinsic task motivation. Academy of Management Review, 15(4): 666681. 